\title{
Identifying cell subtypes in the carotid atherosclerotic plaques by the deconvolution MiRNA analysis
}

\author{
Aleksei Zarubin \\ RIMG TNRMC, Tomsk, Russia \\ aleksei.zarubin@medgenetics.ru
}

\author{
Anton Markoy \\ RIMG TNRMC, Tomsk, Russia \\ anton.markov@medgenetics.ru \\ Maria Nazarenko \\ RIMG TNRMC, Tomsk, Russia \\ maria.nazarenko@medgenetics.ru
}

\author{
Aleksei Sleptcov \\ RIMG TNRMC, Tomsk, Russia \\ alexei.sleptcov@medgenetics.ru
}

\begin{abstract}
MiRNAs are small non-coding RNAs that have a specific cell-type-dependent expression and may be influenced by diseases, such as atherosclerosis. In this study, we demonstrate possibility of determining differentially expressed miRNA genes in cell subtypes by using a cell deconvolution approach.
\end{abstract}

\section{Keywords - atherosclerosis, miRNA, deconvolution}

Motivation and Aim

There has been reported that miRNAs participate in the atherosclerotic process actively. The cell- and tissue-specific manner expression of miRNAs results in a challenging identification of the shifts in expression levels through disease, especially in atherosclerosis. Whether the shifts are caused by a twist of the cell-type ratios or by the intracellular dysregulations are still unclear. We suggest that the cell-type deconvolution algorithms can be helpful to assess the cellular composition of bulk tissue samples [1].

To assess the potential of the deconvolution approaches to simultaneously decomposition onto cell types and detecting expression changes in it on the example miRNA sequencing data of atherosclerosis tissues.

\section{Methods}

Both atherosclerotic-affected and intact tissue of carotid artery biopsy specimens obtained from 5 patients simultaneously. Preparation of miRNA sequencing libraries was carried out by the NEBNext Multiplex Small RNA Library Prep Set for Illumina following with sequencing on the HiSeq 1500 system (1x50bp mode). Data processing and evaluation of miRNA expression were performed using miARma-Seq software package. The pre-made database was used as well (https://github.com/alekseizarubin/miRNA_reference_decon volution arteries). The deconvolution and statistical analysis was executed in the $\mathrm{R}$ software (edgeR, DeconRNASeq, TOAST).

\section{Results}

As a result of the deconvolution, a statistically significant difference of the predicted fraction of macrophages (MF), smooth muscle cells and fibroblasts (SMC_Fib), lymphocytes (T NK and B cells), and neutrophils (NF) was found between atherosclerotic-affected and intact carotid arteries. MiRNAs were differentially expressed in specific cell types (see Table 1). Unfortunately, the identification of expression shifts of miRNAs in endothelial cells (EC) and MF is unfeasible owing to an absence of cell subtypes in the intact tissue specimens.

Thus, we demonstrated possibilities for the utilization of miRNA sequencing data into cell deconvolution analysis to reconstruct cell subtypes proportion and the identification of differentially expressed miRNA genes in them.

TABLE 1. THE PREDICTED FRACTION OF CELL TYPES IN SAMPLES AND DIFFERENTIALLY EXPRESSED MIRNAS

\begin{tabular}{|c|c|c|c|c|c|c|}
\hline 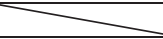 & \multicolumn{6}{|c|}{ Cell subtypes } \\
\hline Sample ID & EC & SMC Fib & MF & T NK & NF & $\mathrm{B}$ \\
\hline iv24 & 0.0 & 0.37 & 0.0 & 0.00 & 0.32 & 0.31 \\
\hline iv27 & 0.0 & 0.52 & 0.0 & 0.00 & 0.30 & 0.18 \\
\hline iv31 & 0.0 & 0.39 & 0.0 & 0.00 & 0.32 & 0.28 \\
\hline iv33 & 0.0 & 0.46 & 0.0 & 0.01 & 0.32 & 0.21 \\
\hline iv34 & 0.0 & 0.43 & 0.0 & 0.00 & 0.35 & 0.23 \\
\hline ap24 & 0.0 & 0.45 & 0.03 & 0.03 & 0.31 & 0.18 \\
\hline ap27 & 0.0 & 0.50 & 0.05 & 0.08 & 0.27 & 0.10 \\
\hline ap31 & 0.0 & 0.47 & 0.02 & 0.06 & 0.32 & 0.13 \\
\hline ap33 & 0.0 & 0.54 & 0.02 & 0.11 & 0.27 & 0.07 \\
\hline ap34 & 0.0 & 0.52 & 0.01 & 0.06 & 0.30 & 0.11 \\
\hline $\begin{array}{c}\text { Differentially } \\
\text { expressed } \\
\text { miRNAs }\end{array}$ & NA & $\begin{array}{c}\text { miR-132 } \\
\text { miR-18a } \\
\text { miR- } \\
323 b \\
\text { miR-410 } \\
\text { miR-126 } \\
\text { miR-10b }\end{array}$ & NA & $\begin{array}{c}\text { miR-654 } \\
\text { miR-410 } \\
\text { miR-323b } \\
\text { miR-504 } \\
\text { miR-24-1 } \\
\text { miR-147b } \\
\text { miR-10a } \\
\text { miR-204 }\end{array}$ & $\begin{array}{c}\text { miR-132 } \\
\text { miR-199b } \\
\text { miR-10b } \\
\text { miR-126 }\end{array}$ & $\begin{array}{l}\text { miR- } \\
199 b\end{array}$ \\
\hline
\end{tabular}

\section{REFERENCES}

[1] Li Z. \& Wu H. (2019). TOAST: improving reference-free cell composition estimation by cross-cell type differential analysis. Genome biology, 20 (1), 190. 